US Army Corps of Engineers ${ }_{\circledast}$

\title{
Mississippi River 2016 Winter Stage Trends
}

MRG\&P Report No. 15 • November 2017

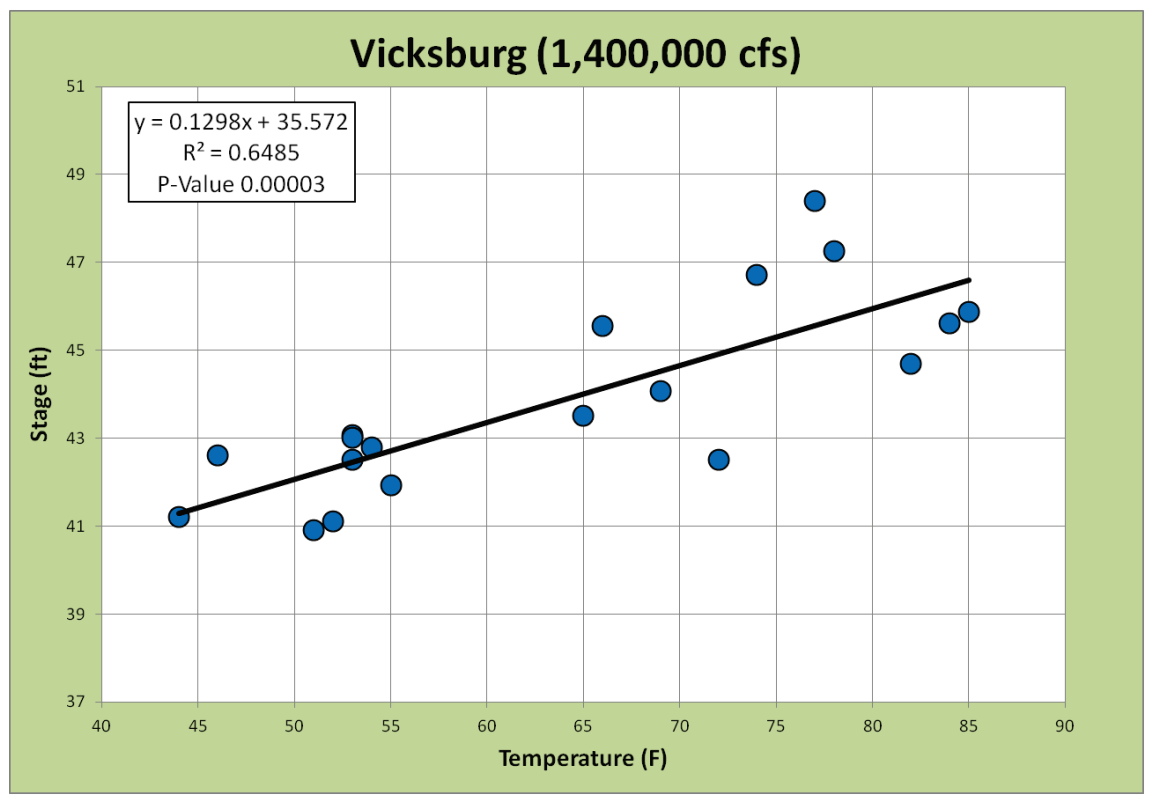

MRG\&P

Mississippi River Geomorphology \& Potamology Program 


\title{
Mississippi River 2016 Winter Stage Trends
}

\author{
David P. May and David S. Biedenharn \\ U.S. Army Engineer Research and Development Center \\ Coastal and Hydraulics Laboratory \\ 3909 Halls Ferry Road \\ Vicksburg, MS 39180 \\ Brian S. Johnson \\ U.S. Army Corps of Engineers \\ Vicksburg District \\ 4155 Clay Street \\ Vicksburg, MS 39180 \\ Edmund Howe \\ U.S. Army Corps of Engineers \\ Memphis District \\ 167 N. Main Street \\ Memphis, TN 38103
}

Final report

Approved for public release; distribution is unlimited.

\author{
Prepared for U.S. Army Corps of Engineers, Mississippi Valley Division \\ Mississippi River Geomorphology and Potamology Program \\ 1400 Walnut Street \\ Vicksburg, MS 39180 \\ Under Project 127672, “2016 Winter Flood investigation”
}




\section{Abstract}

During the winter flood of 2016, concerns were raised about the projected stages being higher than observed and whether these differences reflected some significant morphologic change in the Mississippi River that required attention. To address this issue, a review of research related to cold water versus warm water floods was conducted, followed by an analysis of specific gage records and stage-discharge trends, which had been updated to include data from 2014 through 2016. The gage analysis revealed no stage abnormalities that were considered outside the normal broad-scale trends or typical intra-annual stage variability. Rather, the observed stages appeared to be consistent with typical cold water stage tendencies. Observed stage-temperature data indicate that at the midbank and higher flows, there is a significant association between stage and water temperature. The fact that this apparent paradox does exist suggests that the underlying dominant processes for the differences between cold water and warm water flood stages are not yet fully understood: processes such as floodplain vegetation changes, antecedent flood conditions, or other factors may also be significant contributors.

DISCLAIMER: The contents of this report are not to be used for advertising, publication, or promotional purposes. Citation of trade names does not constitute an official endorsement or approval of the use of such commercial products. All product names and trademarks cited are the property of their respective owners. The findings of this report are not to be construed as an official Department of the Army position unless so designated by other authorized documents. 


\section{Contents}

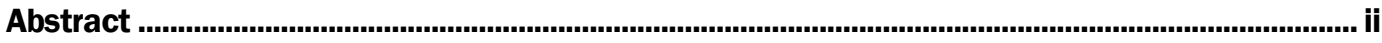

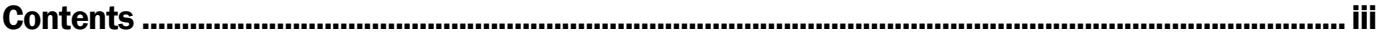

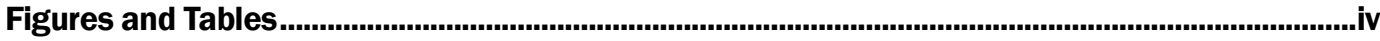

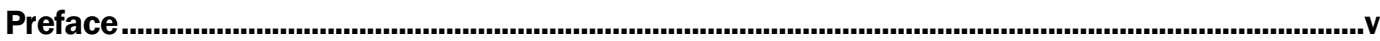

Unit Conversion Factors .....................................................................................................................

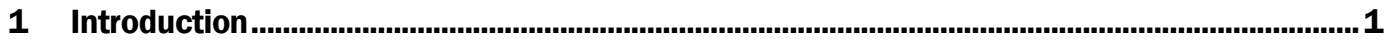

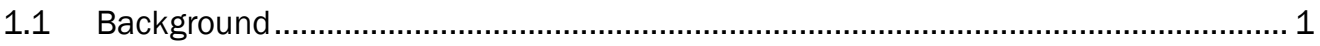

1.2 Objectives and methodology ........................................................................... 1

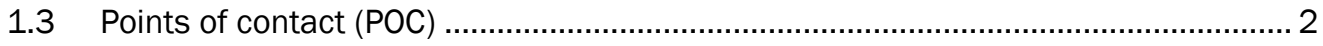

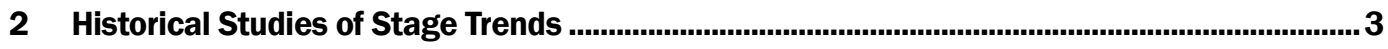

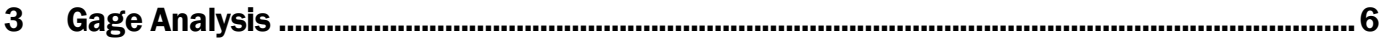

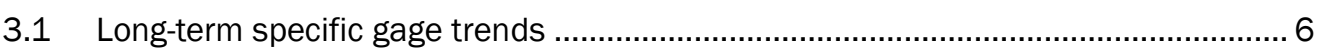

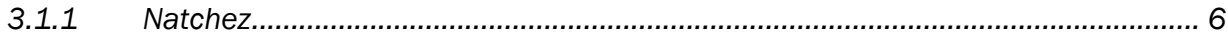

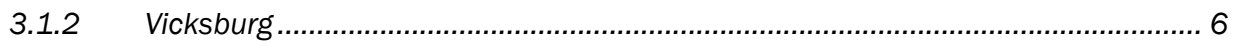

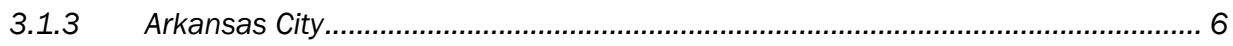

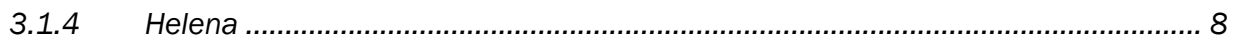

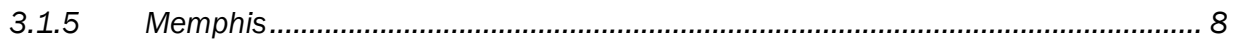

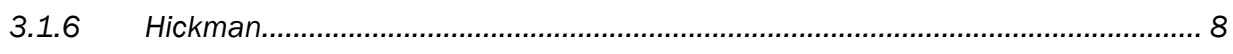

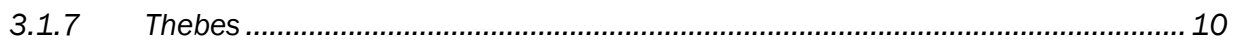

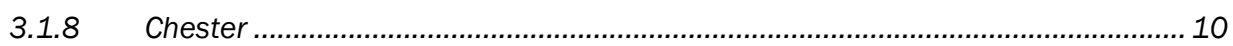

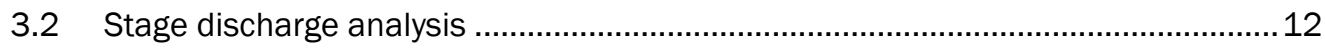

3.2.1 Stage-temperature relationships ...................................................................... 12

3.2.2 Stage-discharge comparisons for recent high flow events................................. 15

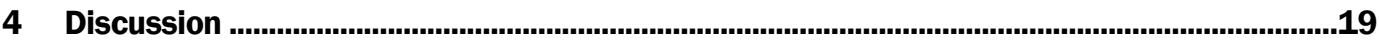

Summary

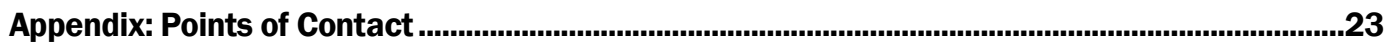

References .......................................................................................................................................24

Report Documentation Page 


\section{Figures}

Figure 3.1. Natchez specific gage Record (1890-2016)....................................................................

Figure 3.2. Vicksburg specific gage Record (1858-2016). ............................................................ 7

Figure 3.3. Arkansas City specific gage Record (1884-2016)....................................................... 8

Figure 3.4. Helena specific gage record $(1882-2016)$..................................................................

Figure 3.5. Memphis specific gage record (1883-2016)...............................................................

Figure 3.6. Hickman specific gage record (1931-2016)...................................................................10

Figure 3.7. Thebes specific gage record (1941-2016)..................................................................11

Figure 3.8. Chester specific gage record (1942-2016) .................................................................11

Figure 3.9. Stage-water temperature trends at Vicksburg for $1,400,000 \mathrm{cfs}$...................................13

Figure 3.10. Stage-water temperature trends at Vicksburg for 1,000,000 cfs.................................13

Figure 3.11. Stage-water temperature trends at Vicksburg for 700,000 cfs. ..................................14

Figure 3.12. Stage-water temperature trends at Vicksburg for 500,000 cfs. ...................................14

Figure 3.13. Stage-water temperature trends at Vicksburg for $250,000 \mathrm{cfs}$...................................15

Figure 3.14. Stage-discharge relationship for 2008, 2011, and 2016 at Natchez...........................17

Figure 3.15. Stage-discharge relationship for 2008, 2011, and 2016 at Vicksburg. .........................17

Figure 3.16. Stage-discharge relationship for 2008, 2011, and 2016 at Hickman..........................18 


\section{Preface}

The research documented in this report was conducted as part of the Mississippi River Geomorphology \& Potamology (MRG\&P) Program, project name "2016 Winter Flood Investigation." The MRG\&P Program is sponsored by Headquarters, U.S. Army Corps of Engineers (USACE), and is managed by the USACE Mississippi Valley Division in Vicksburg, MS. At the time of report production, the MRG\&P Technical Director was Dr. Ty V. Wamsley.

The MVD Commander was MG Richard G. Kaiser. The MVD Director of Programs was Mr. James Bodron.

The Mississippi River Commission provided Mississippi River engineering direction and policy advice. The Commission members were MG Richard G. Kaiser, USACE; the Honorable Sam E. Angel; the Honorable R. D. James; the Honorable Norma Jean Mattei, Ph.D.; RDML Shepard Smith, National Oceanic and Atmospheric Administration (NOAA); BG Mark Toy, USACE; and COL Paul E. Owen, USACE.

The Deputy Director of the U.S. Army Engineer Research and Development Center (ERDC), Coastal and Hydraulics Laboratory, was Mr. Jeffery R. Eckstein, and the Director was Mr. José E. Sánchez.

COL Bryan S. Green was the Commander of ERDC, and the Director was Dr. David W. Pittman. 


\section{Unit Conversion Factors}

\begin{tabular}{|l|c|l|}
\hline Multiply & By & To Obtain \\
\hline cubic feet & 0.02831685 & cubic meters \\
\hline feet & 0.3048 & meters \\
\hline miles (U.S. statute) & $1,609.347$ & meters \\
\hline
\end{tabular}




\section{Introduction}

\subsection{Background}

The Mississippi River and its floodplain have been subjected to numerous natural and anthropogenic factors since the early 1800 . However, the most rigorous and widespread changes occurred after the flood of 1927 with the initiation of the Mississippi River \& Tributaries (MR\&T) Project as part of the Flood Control Act of 1928. The MR\&T is a comprehensive project that includes levees, channel improvements (cutoffs, revetments, dikes, and dredging), and floodways, as well as tributary reservoirs and other basin improvements. The morphology of the Mississippi River reflects an integration of all these features combined with natural factors such as floods and droughts, hurricanes, tectonic activity, geologic outcrops, climatic variability, and sea level rise. In recognition of these complex requirements, such as navigation and flood control, along with the need to consider the sustainability of the system into the next century, the Mississippi River Geomorphology \& Potamology (MRG\&P) Program was developed.

The winter flood of 2016 produced stages at numerous gage locations that were lower than projected flood stages. The lower stages can be partially attributed to reductions in the projected discharges in the system. However, the Mississippi Valley Division (MVD) raised concerns that these stage trends may have been indicative of some significant, yet previously unrecognized, morphologic change or were simply associated with normal intra-annual stage variability. Recognition of the underlying geomorphic processes responsible for these stage trends is critical for the continued successful management of the river system during future floods.

\subsection{Objectives and methodology}

The objectives of this study were to investigate the observed stage trends during the 2016 winter flood and to identify the dominant causative factors responsible for the observed trends. Two specific tasks were involved in this investigation. The first task was to update the specific gage records to include the most recent measurements in 2016. These specific gage trends were then evaluated to document any significant stage trends during the 2016 winter flood that would be indicative of a significant 
morphologic change in the system. The second task was to investigate the underlying causative factors responsible for the observed stage trends. Potential factors to be evaluated included temperature and seasonality effects, as well as local and system-wide morphological adjustments.

\subsection{Points of contact (POC)}

For additional information, POC are located in the Appendix. 


\section{Historical Studies of Stage Trends}

The study of the effect of water temperature on stage, bed formation, and discharge has been approached in different manners over the past several decades by many researchers. Many of the significant studies on this topic took place in the 1960 s in the form of field measurements and flume studies initiated by the U.S. Army Corps of Engineers (USACE) Committee on Channel Stabilization. Initial studies, primarily performed by the USACE, focused on empirical data on specific reaches of rivers such as the Mississippi, Missouri, and Arkansas Rivers. Flume and other laboratory studies were conducted during this time period that often produced results that differed from the empirical study results.

One of the earliest studies of temperature effects on river stage was on the Middle Loup River by Hubbell (1956). The Middle Loup River exhibits relatively constant flow and was shown to have lower Manning's $n$ values when the water temperature is lower. Hubbell also noted an absence of dunes at the crossings during winter. Crossings refers to an area of the river in which the thalweg crosses from one bank of the river to the other in a bend.

The New Orleans District compiled a report for the Channel Stabilization Committee in 1966 that provided an extensive review of the published data pertaining to the effects of water temperature on discharge, stage, and bed configuration on the Lower Mississippi River near Red River Landing (Burke 1966). While this report only focused on one specific reach of the Mississippi River, the conclusions reflect the apparent relationship between water temperature, stage, and bed formations. Burke found that colder water is simply more viscous, resulting in higher concentrations of suspended sediment than is observed in warmer waters. Viscosity, for the purpose of this report, refers to the water's resistance to flow (higher viscosity relates to a higher resistance to flow). In the case of measurements taken near Red River Landing, the river picks up and carries sediment from the crossings during a flood event, and during a cold water flood, this sediment is carried for a longer time period in suspension and not redeposited as quickly. The resulting deeper crossings and increased channel capacity allow cold water floods to pass the same discharge as their warm water counterparts at a lower stage (Burke 1966). 
Flume experiments completed by Franco (1968) and Vanoni and Brooks (1957) yielded results that did not align with the Burke (1966) field observations of the effect of water temperature on stage, discharge, and bed formations. In some instances, the flume results showed opposite effects seen in the field, such as increased bed roughness with decreased temperatures. Discrepancies such as this led many to question the ability of this phenomenon to be captured in a laboratory setting. The results of these flume tests prompted Fenwick (1969) to gather more field data and expand upon the Burke (1966) study. The Fenwick (1969) report examined 31 flow events at 18 gaging stations along the Missouri, Mississippi, and Arkansas Rivers. Note that in every instance the cold water conditions produced higher discharges than the warmer water for both the rising and falling stages. Fenwick (1969) concluded that the bed resistance in large alluvial rivers increases significantly with increasing water temperature so that a given river discharge will pass at a higher stage elevation when the water is warm than when cold. Fenwick (1969) recommended the continuation of laboratory studies on water-temperature effects but also cautioned the use of homogenous sediment, the use of shallow flumes, and the lack of sinuosity present in the former flume studies.

Colby and Scot (1965) provided insight into the complexity of water temperature and the resulting changes in viscosity effects on bed material (larger than .062 millimeters [mm]) discharge. They concluded that water temperature has an appreciable effect on the resistance to flow only within certain ranges of flow and that these ranges are different for different streams. They also asserted that these complex processes could be grouped into three separate effects: (1) the thickness of the laminar sublayer; (2) vertical distribution of the suspended bed material; and (3) bed configuration that could lead to resistance of flow. They concluded that the effect on the vertical distribution of suspended bed material leads to an approximate doubling of bed material discharge if water temperatures are decreased from $80^{\circ} \mathrm{F}$ to $40^{\circ} \mathrm{F}$. They further noted that this effect seems to be the most consistent and predictable of the above three processes. Colby and Scot also proposed five possible reasons that flume studies and field results are different: (1) relative shallowness of flumes: (2) presence of a wide range of Froude numbers and bed configurations for flume flows; (3) the general uniformity of bed configurations over the effective part of the flume bed present at most times during an experiment; (4) the difference in types of data analysis for flume studies and stream studies; and (5) the variability of energy gradients present in flume flows. 
The USACE Omaha District conducted regime studies on the Missouri River for the period 1966-1968 and concluded that there was a pronounced correlation between water temperature, shifts in the stagedischarge relationship, and bed roughness forms (USACE 1969). The bed material near Omaha consists of sediment in the $0.2 \mathrm{~mm}$ size range, and the discharge is controlled by the Gavin's Point Dam upstream. Controlled flow on the Missouri River ranged from 30,000 cubic feet per second (cfs) to 35,000 cfs during the navigation season at the time of the study. These flows proved to be favorable for the study of the effects of temperature on the stage-discharge relationship for stages below bankfull conditions. Field surveys for this study included profiles of both the channel centerline and river cross sections throughout the reach. Measurements included water surface profiles, bed surface sampling, and suspended sediment sampling.

These USACE (1969) studies showed that the water surface of the Missouri River at Omaha lowered, with no reduction in discharge, from 1 to 2 feet ( $\mathrm{ft}$ ) between the months of September and November. This shift in stage coincides with a steady decrease in water temperature of approximately $30{ }^{\circ} \mathrm{F}$ during the period. The effect of temperature on suspended sediment was evident in the study with measurements indicating that the sand load was nearly doubled during November when compared to the August/ September time period. Evidence of the higher suspended sediment concentration was also evident in the observed transformation of the bed forms. Throughout the study it became apparent that the channel bed becomes progressively smoother from the summer into the fall months. The dunes were relatively shorter in length and higher during the summer and became longer and shallower later in the fall. These transitions occurred as the discharge remained relatively constant while temperature decreased. It was also noted that the reversal of this process could be seen during the transition into spring, thus leading the investigators to the conclusion that this process was correlated with temperature. Manning's $n$ values were calculated during this time period and also reflected the smoothing of the bed; Manning's $n$ values decreased from 0.0195 to 0.0155 from September to November. The overall conclusion of the USACE (1969) study on the Missouri River was that stage changes reflected a change of overall channel resistance rather than a lowering of the bed profile or other change in channel dimensions and that these changes were closely associated with changes in water temperature. 


\section{Gage Analysis}

\subsection{Long-term specific gage trends}

Specific gage analysis is a powerful tool used by river engineers and scientists to assess the historical behavior of rivers. In a recent study, specific gage records were developed for 25 stations on the Mississippi River by Biedenharn et al. (2017). The period of record for these stations generally extended through 2014. As part of this present study, the specific gage records at the major gaging stations were extended through 2016 to determine if any significant stage trends occurred during the past several years. A brief discussion of each of these records is provided below.

\subsubsection{Natchez}

Natchez is a primary station located at River Mile (RM) 363.3 above head of passes on the Lower Mississippi River (LMR). The original period of record for the specific gage analysis extended from 1890 to 2014. The updated specific gage record with data through 2016 is shown in Figure 3.1. There is considerable stage variation within any given year, but in general, the Natchez gage has been in an aggradational regime since the mid-1970s. No significant departures from this trend were observed by the addition of the 2015 and 2016 data.

\subsubsection{Vicksburg}

The original period of record for the Vicksburg gage (RM 435.7) extended from 1858 through 2014. The updated specific gage record, extending through 2016, is shown in Figure 3.2. As noted at Natchez, there is considerable variability with any given year, and the 2015 and 2016 data appear to fall within this range with no significant outliers.

\subsubsection{Arkansas City}

Arkansas City is located at RM 554.1 and had an original period of record extending from 1884 through 2014. Discharge measurements were discontinued at Arkansas City in 2011 and replaced by the gage located at Greenville (RM 531.5). Therefore, daily stages at Arkansas City were combined with the observed discharge measurements at Greenville (with no lag) to produce the specific gage at Arkansas City for the 2011 to 2016 period (Figure 3.3). Again, the addition of the 2015 and 2016 data does not reveal any significant deviations from the existing stage trends. 
Figure 3.1. Natchez specific gage Record (1890-2016).

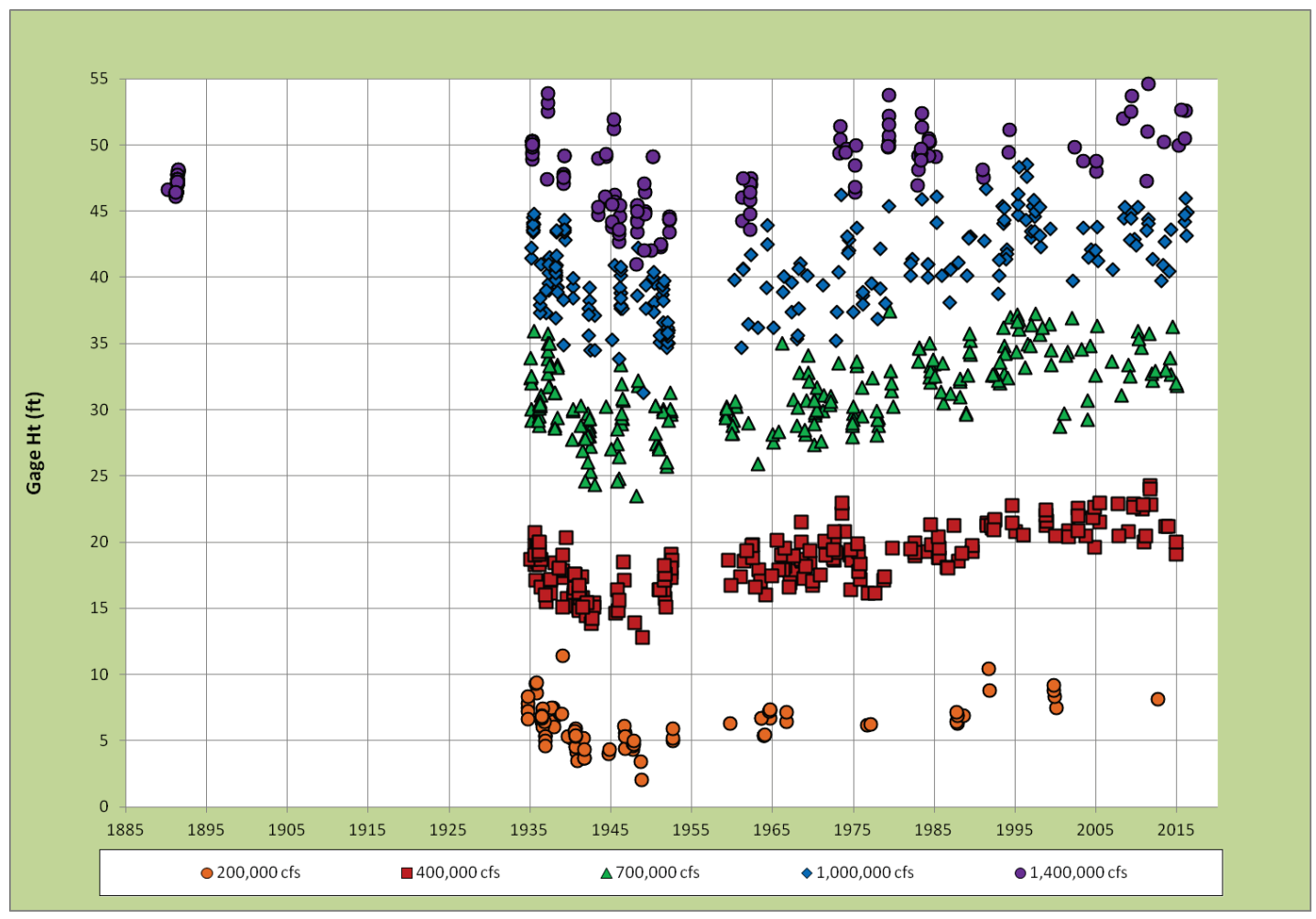

Figure 3.2. Vicksburg specific gage Record (1858-2016).

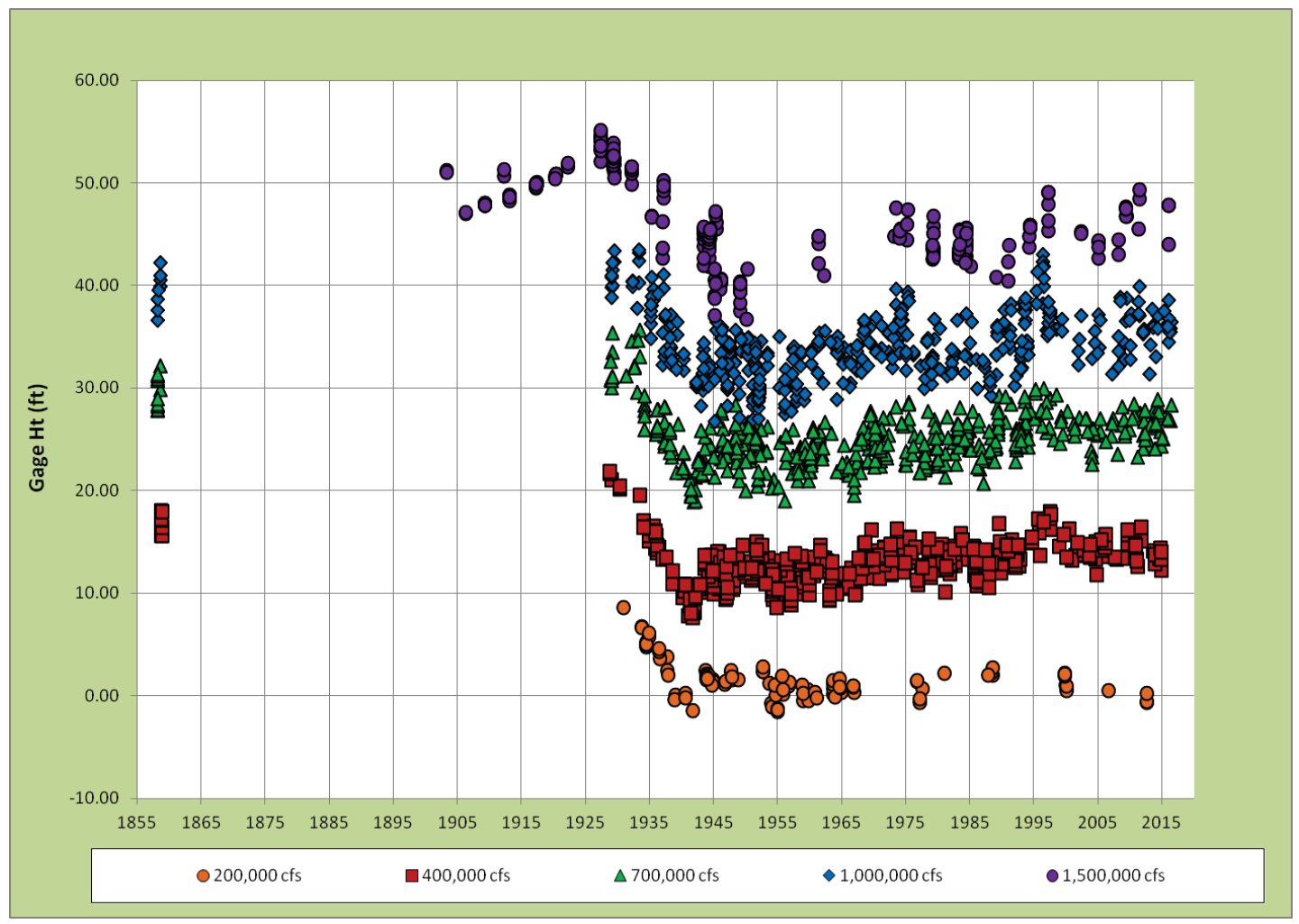


Figure 3.3. Arkansas City specific gage Record (1884-2016).

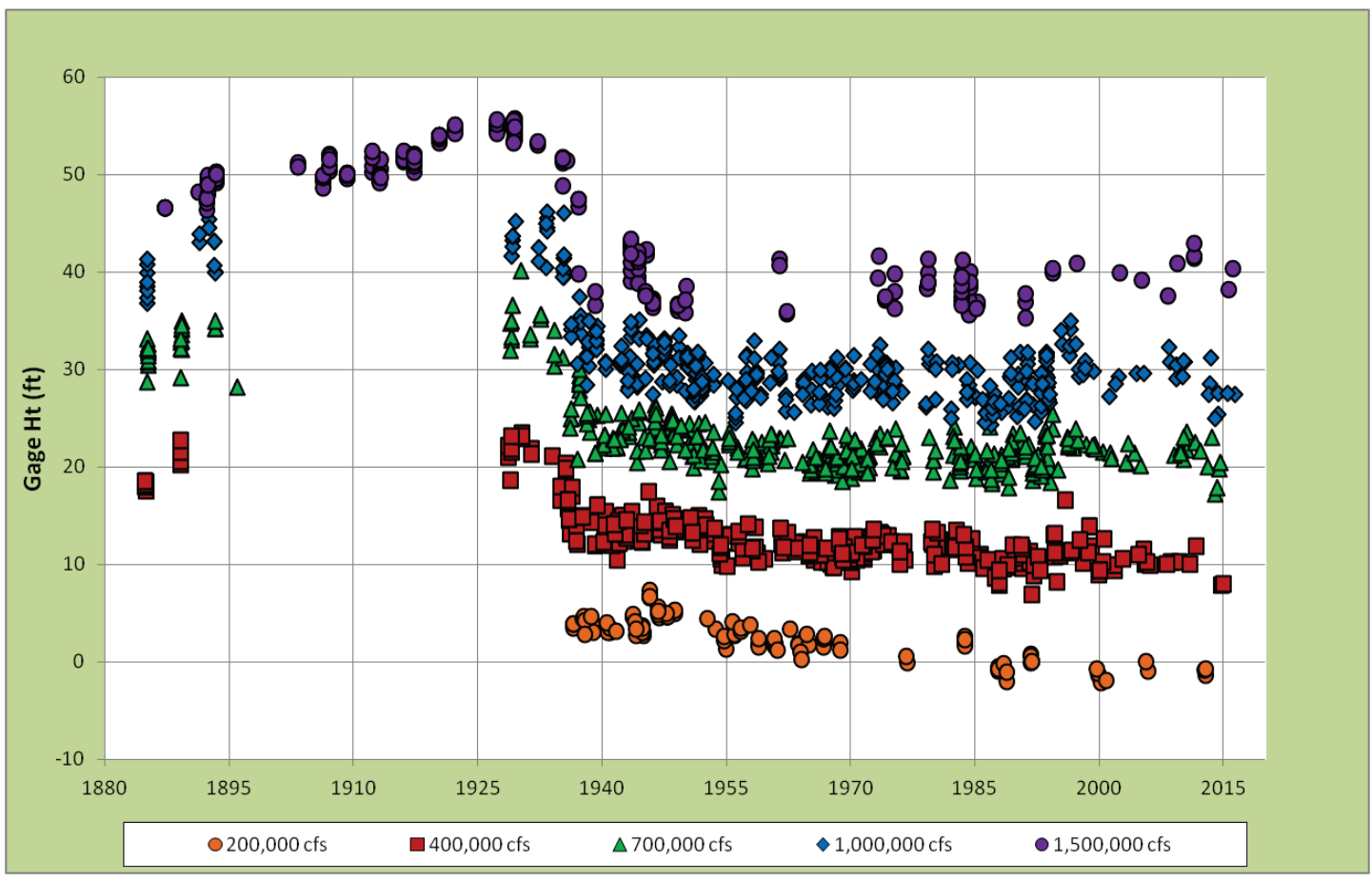

\subsubsection{Helena}

The original period of record for the Helena gage (RM 663) extended from 1882 through 2014. The specific gage record was updated through 2016 (Figure 3.4), although there were only four additional measurements taken between 2015 and 2016. Because of the few data points, the addition of the 2015 and 2016 data is of limited value.

\subsubsection{Memphis}

The Memphis gage is located at RM 734.7 and had an original period of record from 1882 through 2014. The updated specific gage record through 2016 is shown in Figure 3.5. Only three additional measurements were available for 2015 and 2016. Therefore, like Helena, there was not much additional insight provided by these additional data.

\subsubsection{Hickman}

The Hickman gage is located at RM 922 and represents the most upstream primary gage on the LMR. The original period of record at Hickman extended from 1931 to 2013. The updated specific gage record at Hickman with data through 2016 is shown in Figure 3.6. The additional 3 years of data do not indicate any significant deviations from the existing trends. 
Figure 3.4. Helena specific gage record (1882-2016).

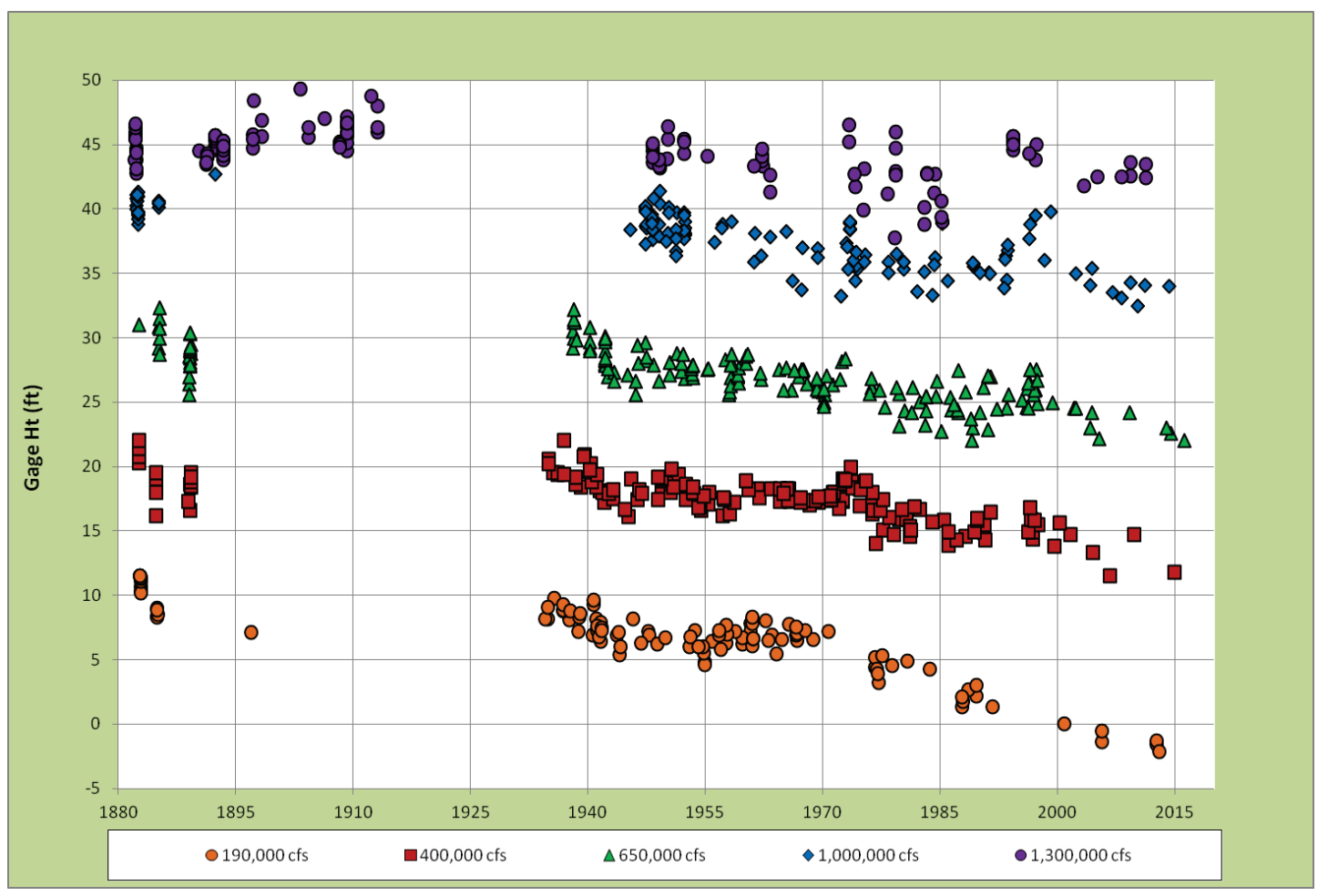

Figure 3.5. Memphis specific gage record (1883-2016).

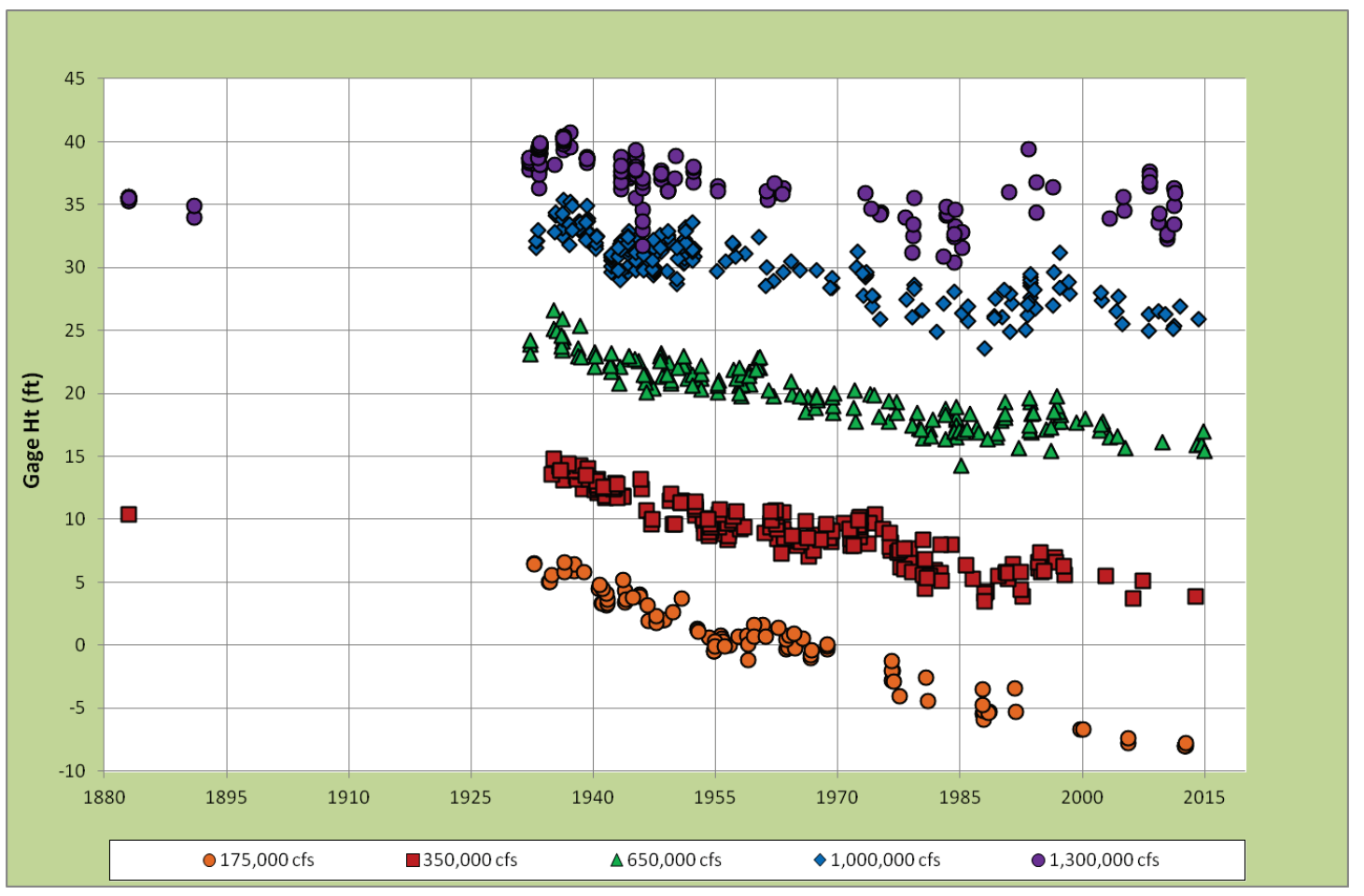


Figure 3.6. Hickman specific gage record (1931-2016).

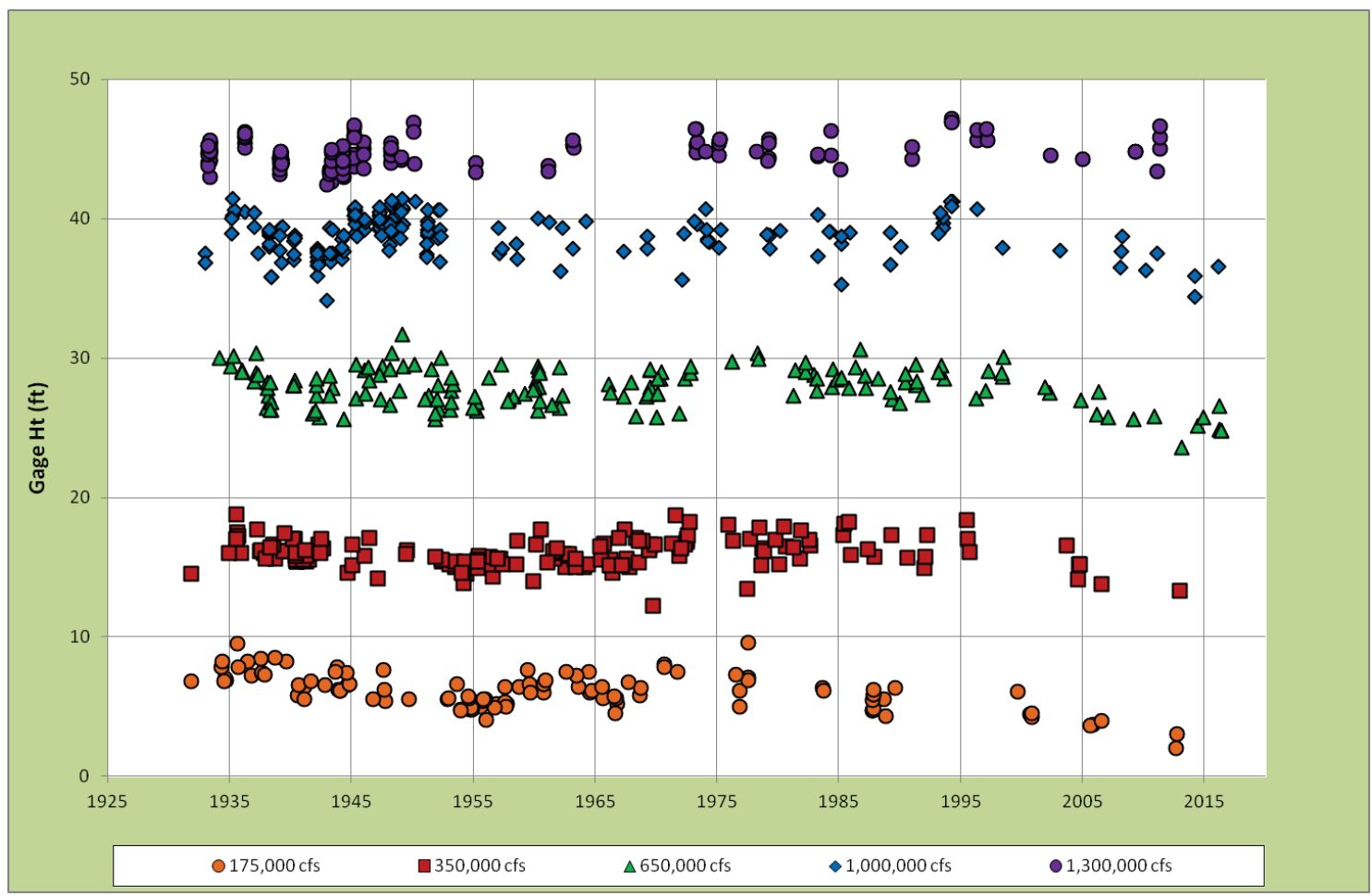

\subsubsection{Thebes}

The Thebes gage is located at RM 43.7 on the Middle Mississippi River (MMR) upstream of the confluence with the Ohio River. The original period of record extended from 1941 through 2014. The specific gage record was updated to include data through 2016, and the resulting graph is shown in Figure 3.7. With exception of a slight increase in the stage for the one measurement at 675,000 cfs, the updated specific gage record does not indicate any significant shifts in the stage trends.

\subsubsection{Chester}

The Chester gage is located at RM 109.9 on the MMR. The original period of record, which extended from 1942 to 2014, was updated to 2016 (Figure 3.8). No significant stage shifts were indicated by the extension of the record. 
Figure 3.7. Thebes specific gage record (1941-2016).

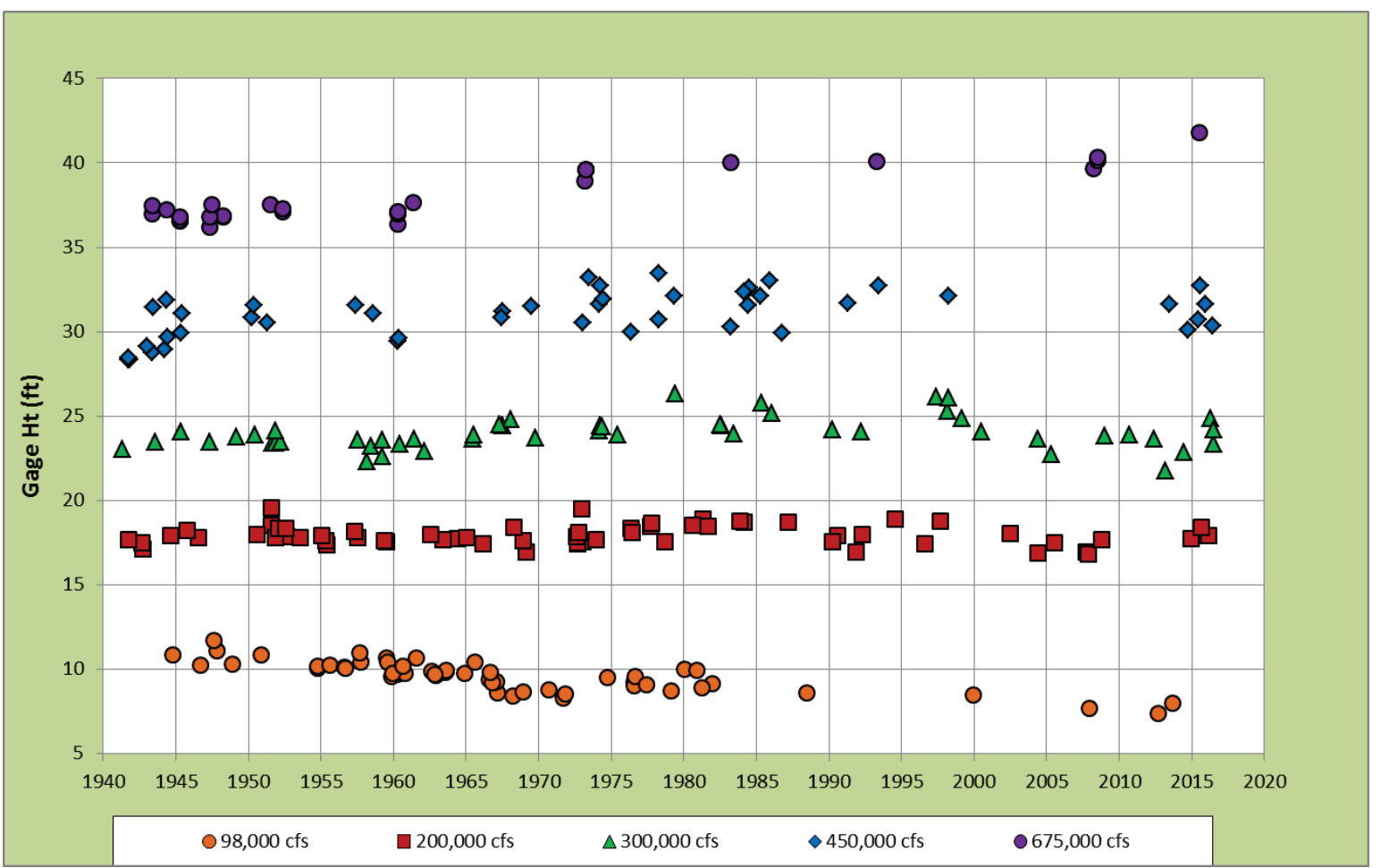

Figure 3.8. Chester specific gage record (1942-2016).

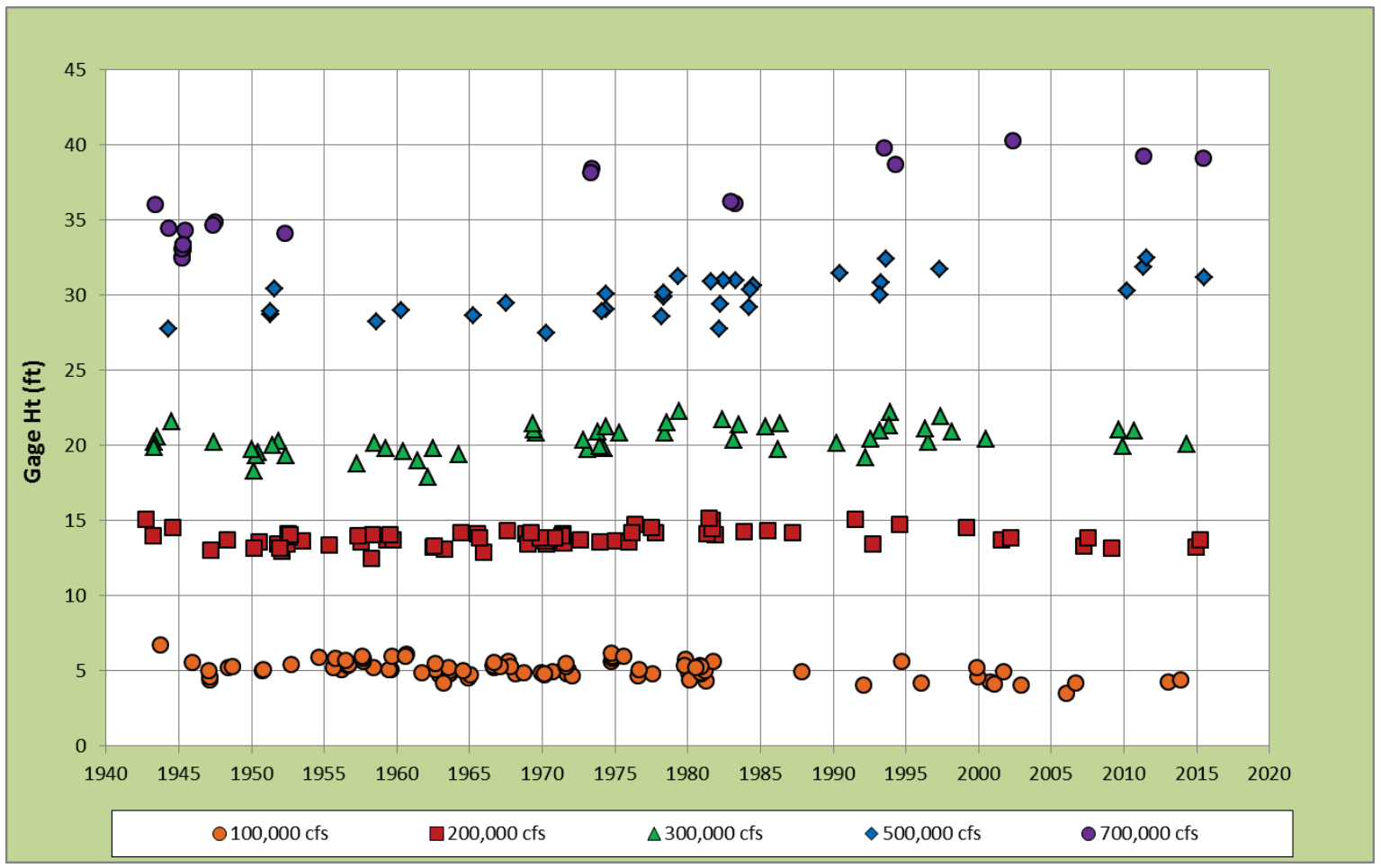




\subsection{Stage discharge analysis}

The specific gage records provide valuable insight into the long-term morphological behavior of the river. However, some of the short term (e.g., seasonal, inter-annual, and flood-related) variability may be obscured in the broad-scale specific gage records. Therefore, a more detailed study of the stage, discharge, and temperature data at selected gaging stations was conducted.

\subsubsection{Stage-temperature relationships}

As discussed in Section 3, the effects of temperature on river stage have been addressed by numerous investigators over the years, often with conflicting results. To illustrate the relationship between stage and temperature, the 2000-2016 data at the Vicksburg gage were analyzed. Five flows (250,000 cfs, $500,000 \mathrm{cfs}, 750,000 \mathrm{cfs}, 1,000,000 \mathrm{cfs}$, and $1,400,000 \mathrm{cfs}$ ) were selected. A flow bin for discharge was selected using bin width of $+/-2.5 \%$. For example, the $1,000,000$ cfs flow was represented by all flows between 950,000 cfs and 1,050,000 cfs. Next, the stage and water temperature data recorded on the observed discharge measurement were plotted for each of the five flows. The results are shown in Figures 3.9 to 3.13. A regression line was developed for each flow.

To assist in the interpretation of the data, the statistical parameters $\mathrm{R}^{2}$ and $\mathrm{P}$-values were determined. The $\mathrm{R}^{2}$ value provides a measure of the amount of variability in $\mathrm{Y}$ (stage) that is explained by $\mathrm{X}$ (temperature). For example, an $\mathrm{R}^{2}$ of 0.8 implies that $80 \%$ of the variability in stage can be explained by a linear relationship with temperature. Conversely, an $\mathrm{R}^{2}$ of 0.2 implies that only $20 \%$ of the variability in stage can be explained by a linear relationship with temperature. The P-value assesses the statistical significance of an apparent trend. For this case, a P-value of 0.05 was used to establish if the slope of the line was statistically different from zero. If the calculated P-value is less than 0.05, then the slope of the trend line is classified as being statistically different than zero: a trend does exist. If the $\mathrm{P}$-value is greater than 0.05 , then the slope of the trend line is not significantly different than zero: there is no significant trend in the series. 
Figure 3.9. Stage-water temperature trends at Vicksburg for $1,400,000 \mathrm{cfs}$.

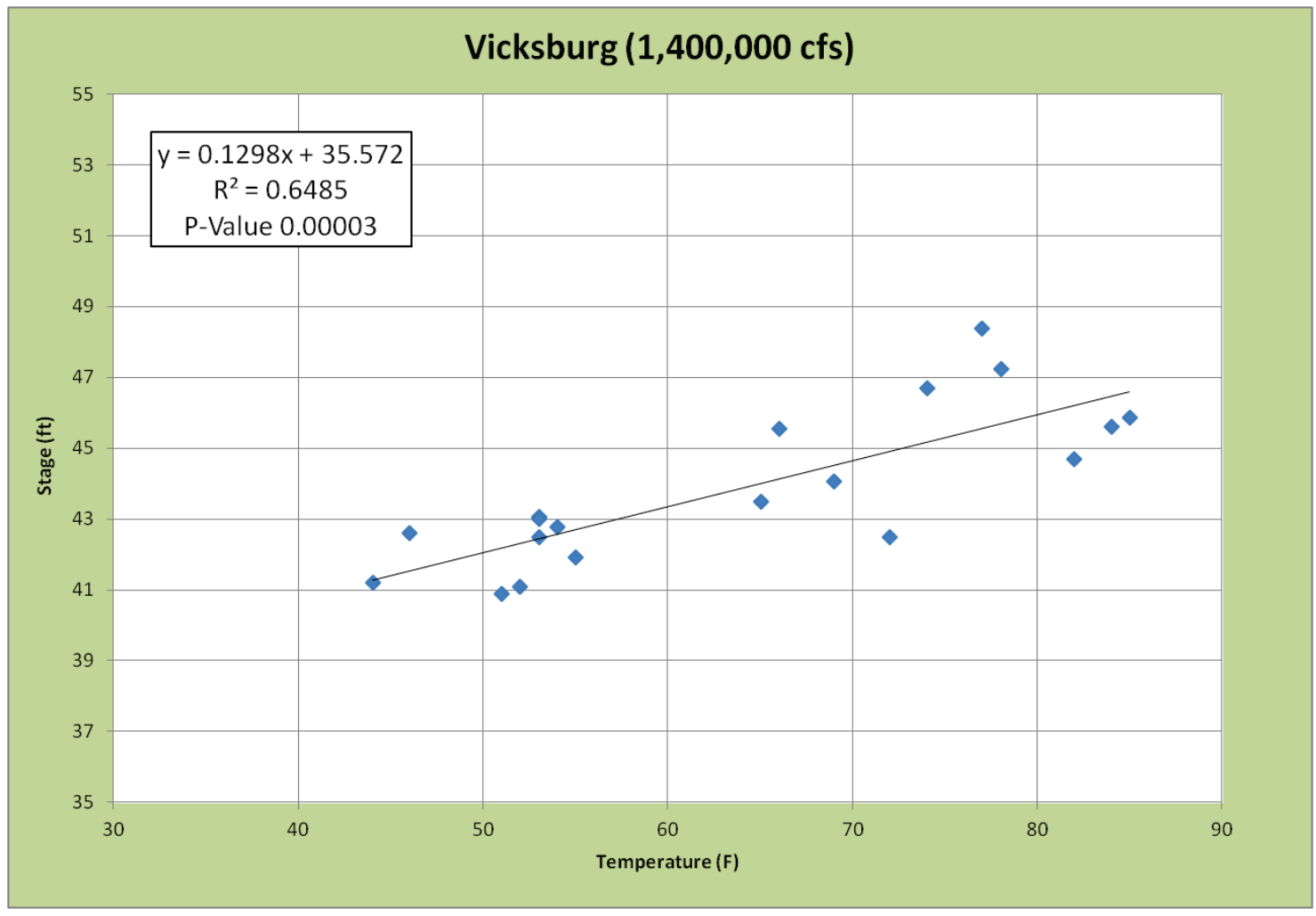

Figure 3.10. Stage-water temperature trends at Vicksburg for 1,000,000 cfs.

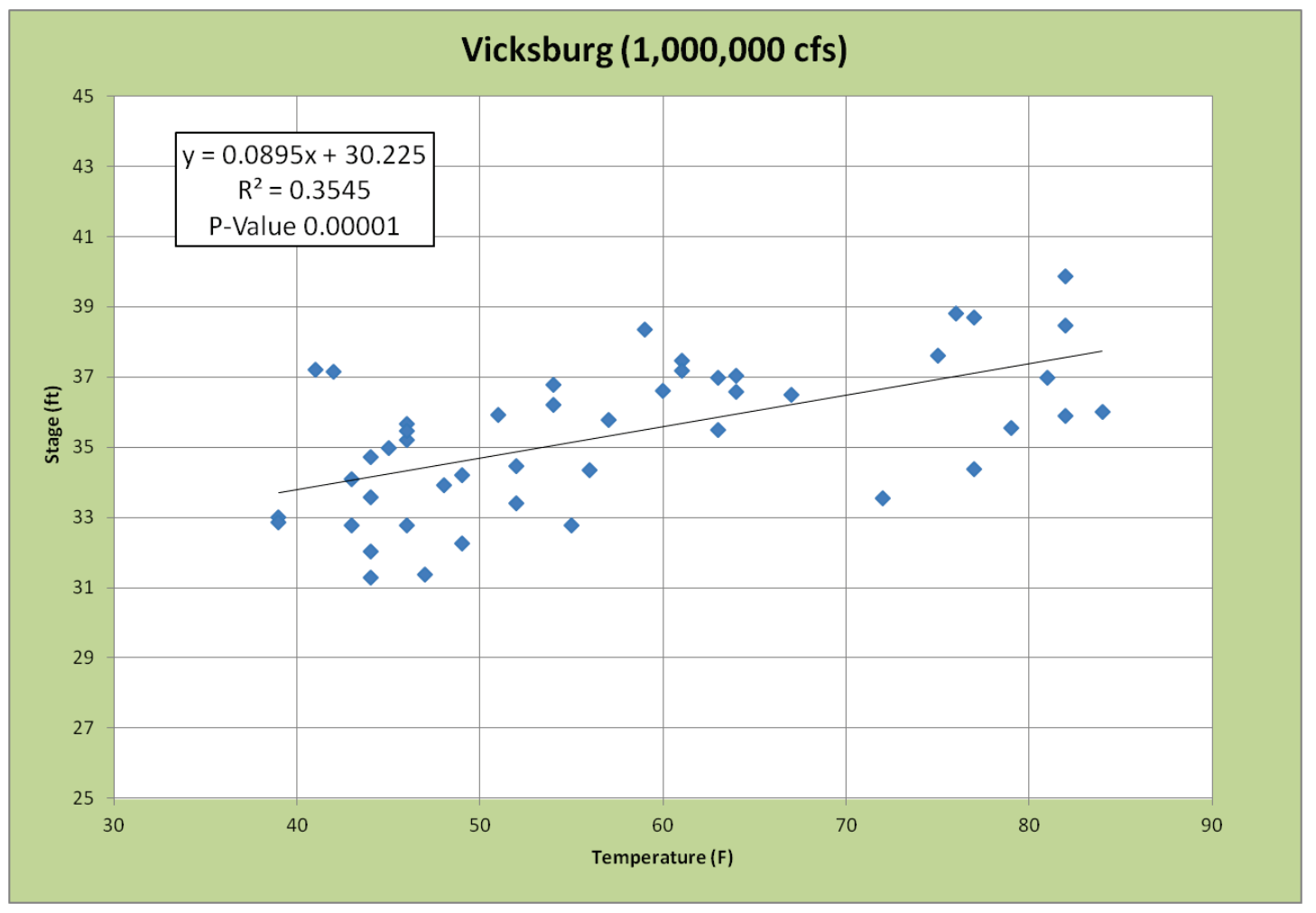


Figure 3.11. Stage-water temperature trends at Vicksburg for 700,000 cfs.

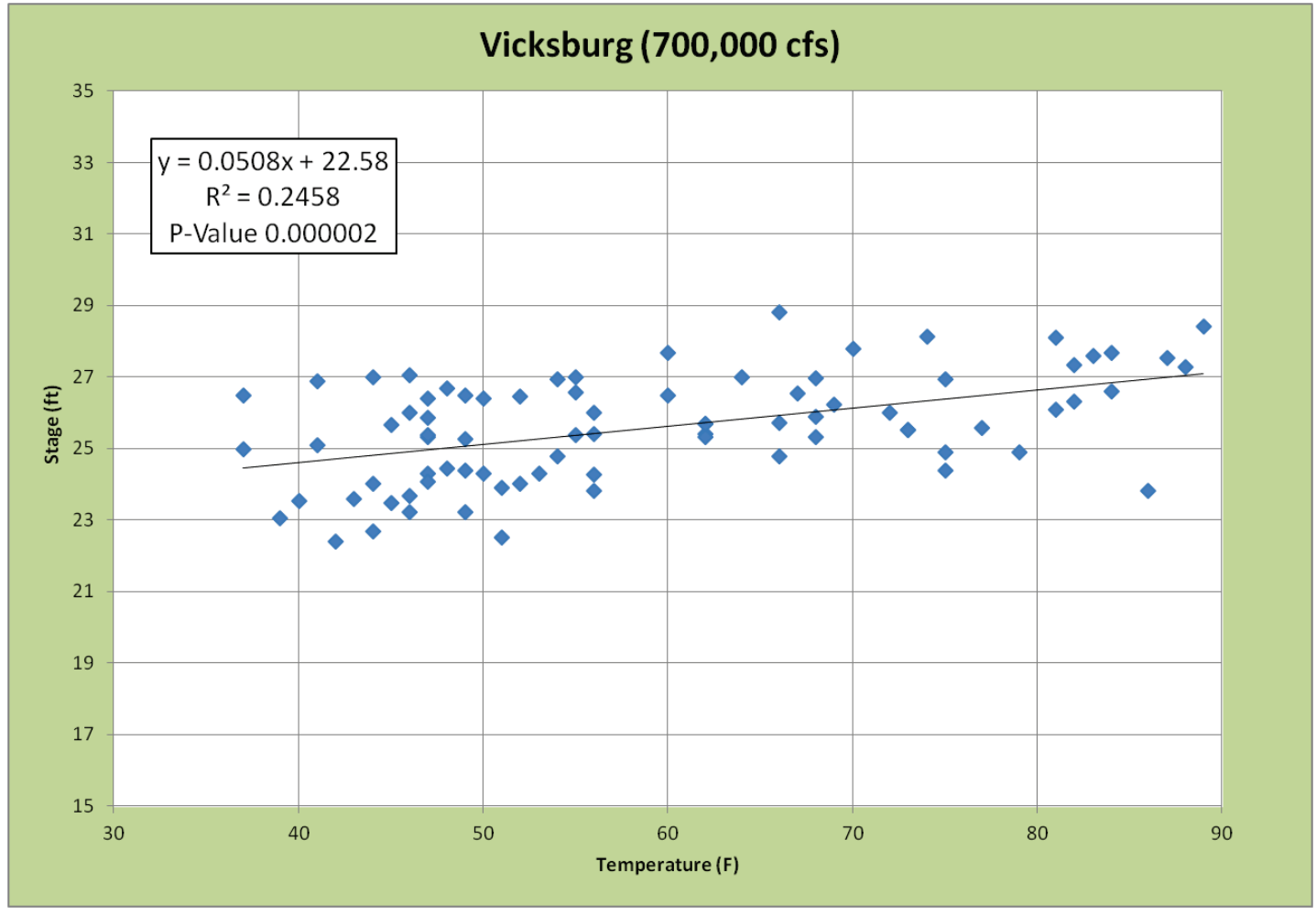

Figure 3.12. Stage-water temperature trends at Vicksburg for 500,000 cfs.

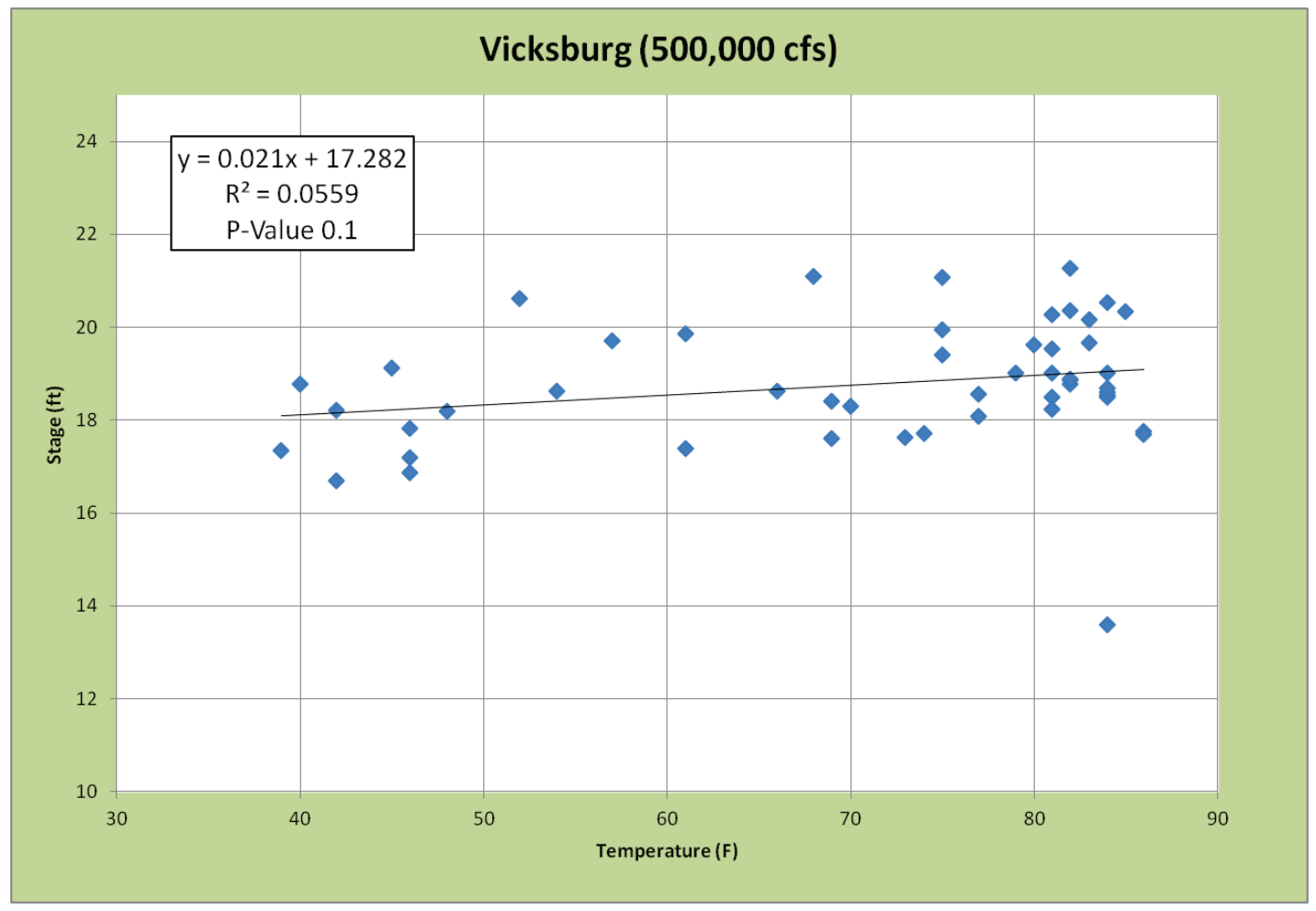


Figure 3.13. Stage-water temperature trends at Vicksburg for 250,000 cfs.

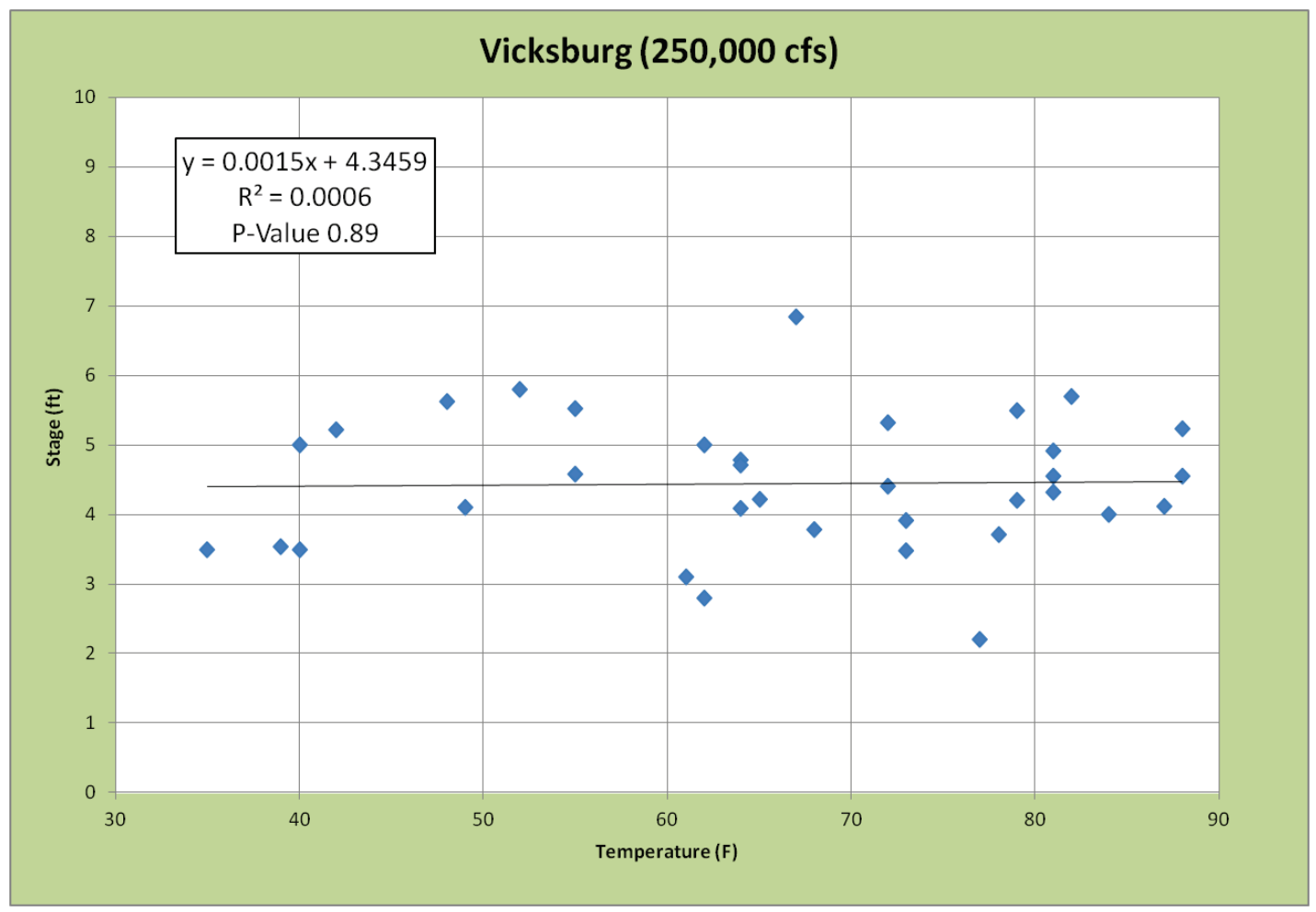

As shown in Figures 3.9 to 3.11, there is a significant increasing trend in stage as temperature increases for the higher flows (700,000 cfs, $1,000,000 \mathrm{cfs}$, and 1,400,000 cfs). At the 1,400,000 cfs flow, there is almost a $6 \mathrm{ft}$ increase in stage associated with a water temperature increase from $45{ }^{\circ} \mathrm{F}$ to $85^{\circ} \mathrm{F}$. At 1,000,000 cfs and 700,000 cfs, the stage increases about $3.5 \mathrm{ft}$ and $2 \mathrm{ft}$, respectively, indicating that the effects of temperature are less at the lower flows. In fact, at even lower flows (500,000 cfs and 250,000 cfs), there does not appear to be any significant relationship between stage and water temperature.

\subsubsection{Stage-discharge comparisons for recent high flow events}

Stage-discharge trends were examined for selected LMR stations for the 2008, 2011, and 2016 flow events. The stations analyzed were Natchez, Vicksburg, and Hickman. The limited number of measurements in 2016 at Helena and Memphis precluded the use of these stations in this analysis. The stage-discharge trends for the three flood years for each of these stations are shown in Figures 3.14 to 3.16. The three floods peaked in April 2008, May 2011, and January 2016. 
As shown in Figures 3.14 and 3.15, the 2008 and 2016 floods follow a similar pattern at Natchez and Vicksburg. For both years, the maximum measured discharge was at or slightly above $1,800,000 \mathrm{cfs}$, and the rising and falling limbs tracked very closely. The hysteresis loop effects are clearly evident in both years, with recessional stages being 2 to $4 \mathrm{ft}$ higher than on the rising limb. In 2011, the stages on the rising limb coincided closely with 2008 and 2016, but stages continued to rise with a maximum measured discharge occurring at approximately 2,300,000 cfs. The 2011 loop effect was larger than the 2008 and 2016 floods, with recessional stages being as much as $5 \mathrm{ft}$ higher than the rising stages. These recessional stages in 2011 were also 2 to $3 \mathrm{ft}$ higher than the 2008 and 2016 stages for flows near $1,800,000$ cfs. The 2011 recessional stages coalesced with the 2008 and 2016 recessional stages approximately $1,300,000 \mathrm{cfs}$.

The stage-discharge relations were also examined at Hickman for the 2008, 2011, and 2016 floods (Figure 3.16). There was a discharge measurement on 28 October 2015, with a flow of 194,000 cfs, and the next measurement was not until 1 January 2016 when the flow was already at $1,650,000 \mathrm{cfs}$. Therefore, there were very limited data for the rising limb of the 2016 flood. As shown in Figure 3.16, the 2016 stages were approximately 4 to $5 \mathrm{ft}$ lower than the 2011 stages near the peak at approximately 1,700,000 cfs. The 2008 flood peaked somewhat lower at approximately 1,400,000 cfs, and its stages near the peak were only approximately $1.5 \mathrm{ft}$ higher than the 2016 stages. Unfortunately, there were no water temperature data available for the Hickman site. 
Figure 3.14. Stage-discharge relationship for 2008, 2011, and 2016 at Natchez.

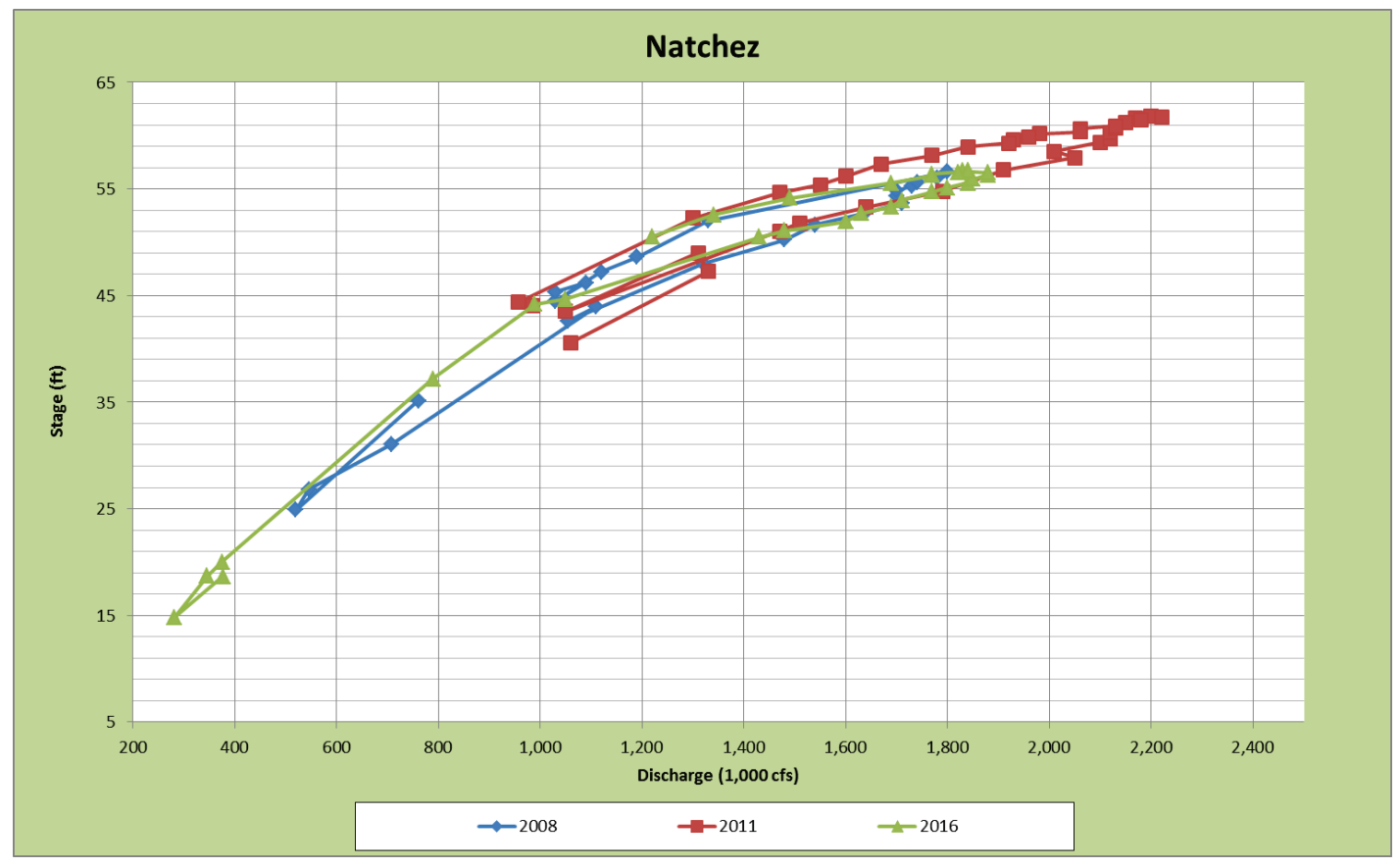

Figure 3.15. Stage-discharge relationship for 2008, 2011, and 2016 at Vicksburg.

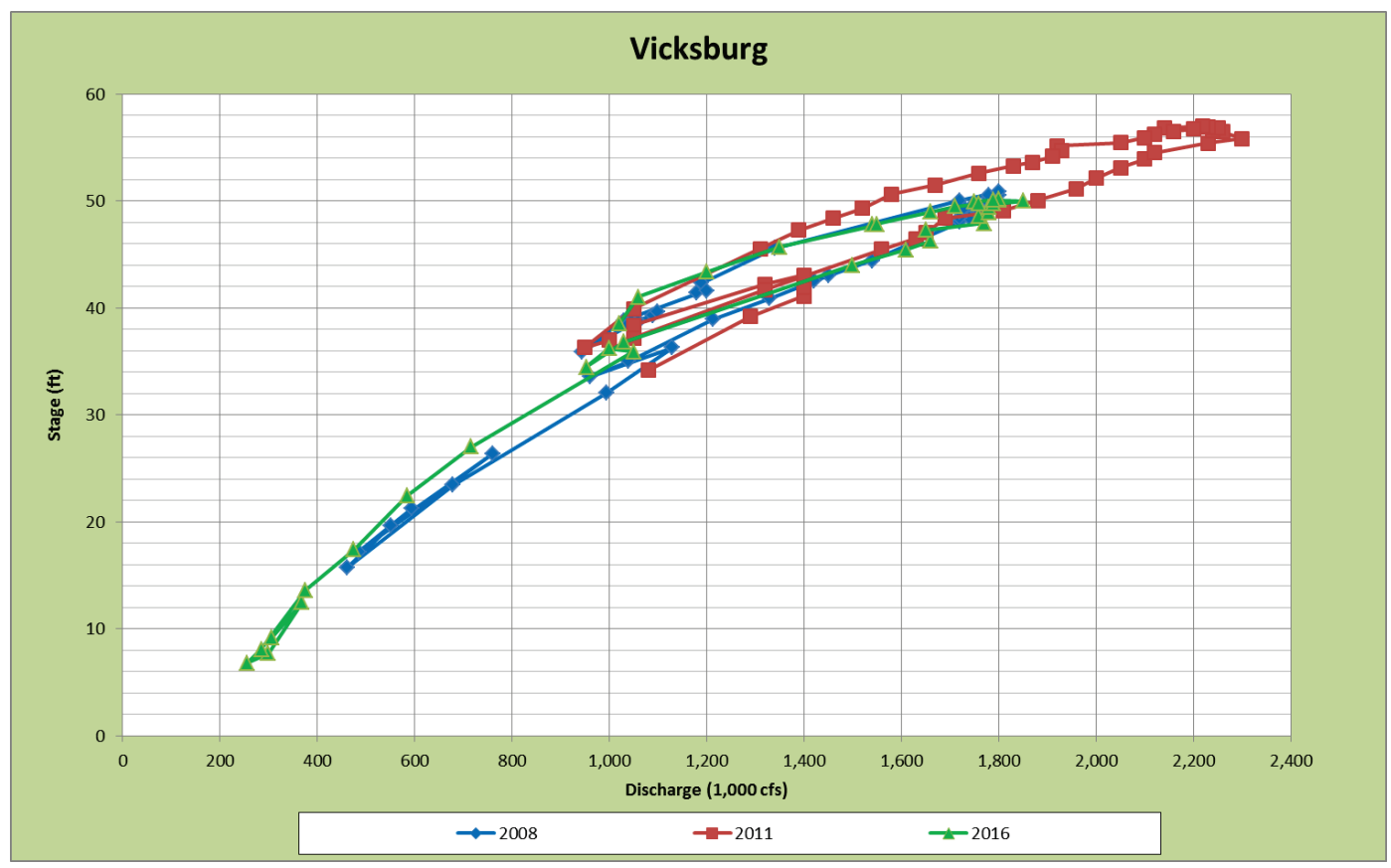


Figure 3.16. Stage-discharge relationship for 2008, 2011, and 2016 at Hickman.

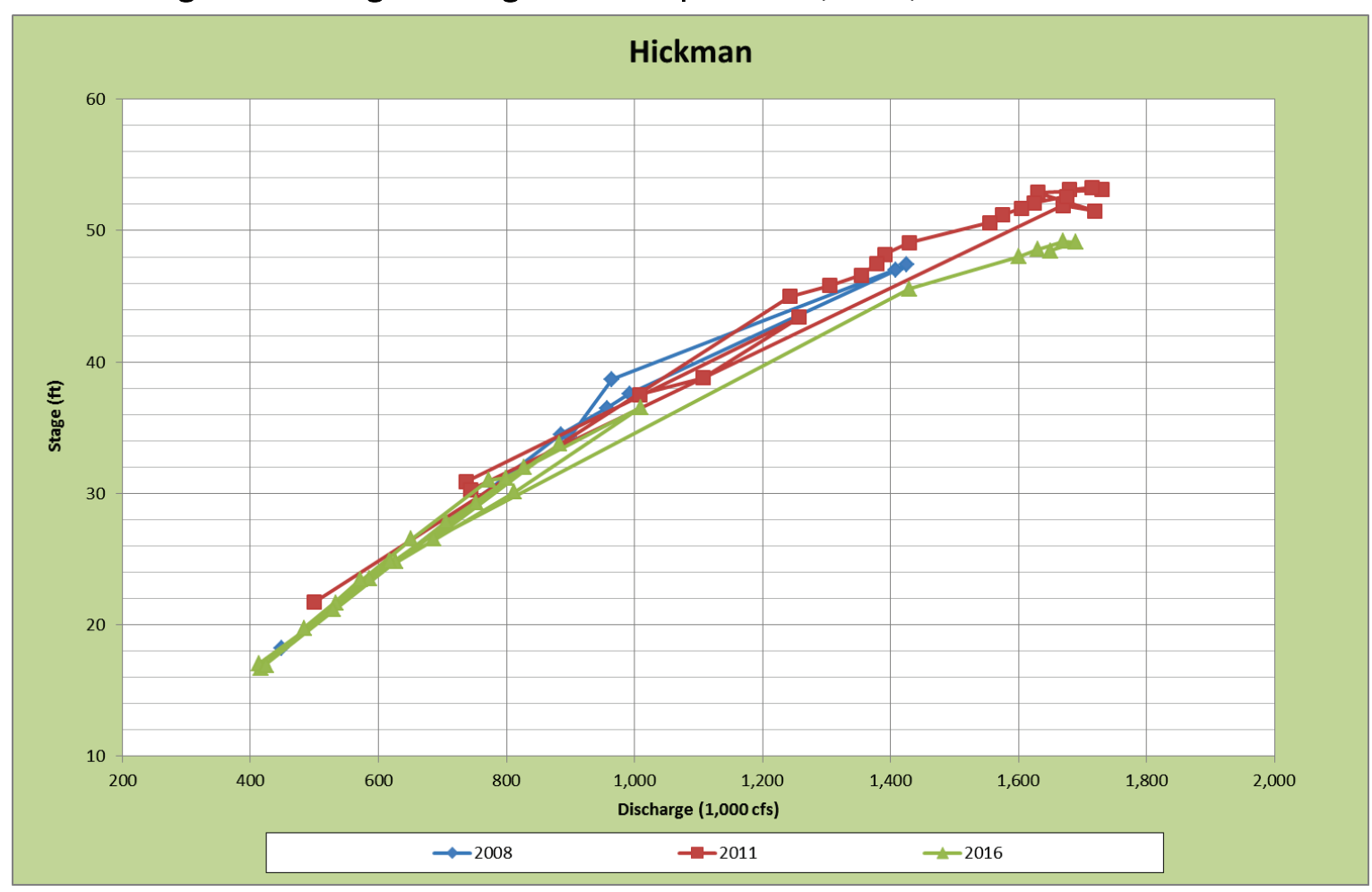




\section{Discussion}

Researchers have examined the cold water versus warm water phenomenon since the 1950s, with the focus being on temperature-related viscosity changes that affect sediment transport, bed forms, and flow resistance. Empirical studies have consistently reported that stages are lower for cold water (winter) floods compared to warm water (spring) floods of the same flow magnitude. However, flume studies have reported just the opposite: cold water flows having higher stages than warm water flows. Although possible explanations for these differences have been proposed, the fact that this apparent paradox does exist suggests that the underlying dominant processes for the differences between cold water and warm water flood stages are not yet fully understood: other processes such as floodplain vegetation changes, antecedent flood conditions, or other factors may also be significant contributors.

The effects of water temperature on the stage-discharge relationship were analyzed for five flows (250,000 cfs, $500,000 \mathrm{cfs}, 750,000 \mathrm{cfs}, 1,000,000$ cfs, and 1,400,000 cfs) at Vicksburg. These data clearly indicate a significant association between water temperature and stage for flows in excess of approximately 700,000 cfs. The strongest association occurred at $1,400,000 \mathrm{cfs}$ with the stages increasing by almost $6 \mathrm{ft}$ as water temperature increased from approximately $45^{\circ} \mathrm{F}$ to $85^{\circ} \mathrm{F}$. At 1,000,000 cfs and $700,000 \mathrm{cfs}$, the stage increases were in the 2 to $3.5 \mathrm{ft}$ range, suggesting that the effects of water temperature are lessened as the flow decreases. This trend is confirmed when the lower flows were examined: at flows of 500,000 cfs and 250,000 cfs, there was no statistically significant association between stage and water temperature.

At this point, a word of caution is needed concerning the observed associations between water temperature and stage. Water temperature is an easily measured parameter and as such is relatively straightforward to use as an independent variable when developing relationships with other dependent variables such as stage. The empirical evidence clearly indicates that cold water floods typically have lower stages than warm water floods. However, the causative factors that are associated with water temperature are not clearly understood. Most researchers have focused attention on the effects of water temperature on sediment transport, bed form roughness, and the resulting stage impacts. However, there may also be other factors contributing to the observed stage trends, which tend to yield greater stage 
differences at higher discharges. For example, cold water floods typically occur in the winter when floodplain vegetation is sparse, thereby lowering the resistance to flow. Another possible contributing factor may be the impact of antecedent conditions. Winter floods, occurring early in the season, have typically not had many large sediment mobilizing flows that might increase bed forms. Therefore, the associated roughness might be lower than during the later spring floods that might have experienced numerous sediment mobilizing flows prior to the major flood event.

Specific gage records were updated to include data through 2016 at eight stations (Natchez, Vicksburg, Arkansas City, Helena, Memphis, Hickman, Thebes, and Chester). This generally involved adding data from 2014 through 2016. Analysis of the specific gage records revealed no stage abnormalities that were considered outside the normal broad-scale trends or intra-annual variability. Note that specific gage records are most applicable for establishing long-term trends over multiples of years or decades. Consequently, the uncertainty associated with focusing on short time periods of a few years, particularly at the end of the record such as in this study, must be recognized.

Stage-discharge trends were examined at Natchez, Vicksburg, and Hickman for the 2008, 2011, and 2016 flow events. At Vicksburg and Natchez, the 2008 and 2016 floods had maximum measured discharges of approximately $1,800,000 \mathrm{cfs}$. Therefore, the 2008 flood provides a similar magnitude event to compare stage trends with the 2016 flood. Comparison of these three events revealed that on the rising limb up to approximately $1,800,000 \mathrm{cfs}$, the curves were nearly coincident. The average water temperature during these rise to approximately $1,800,000 \mathrm{cfs}$ in 2008 , and 2016 water temperatures were approximately $56^{\circ} \mathrm{F}$ and $46^{\circ} \mathrm{F}$, respectively. Thus, the water temperatures for both events were relatively cool during the rising limb of the curves. The recessional stages were also similar in 2008 and 2016, with stages being approximately 2 to $3 \mathrm{ft}$ higher than on the rising limbs. The average water temperature on the recession in 2008 was only slightly higher $\left(62^{\circ} \mathrm{F}\right)$ than on the rising limb whereas in 2016 the average water temperature was actually slightly lower $\left(42^{\circ} \mathrm{F}\right)$ on the recession. The 2016 average water temperatures during the rising and falling limbs were approximately $10^{\circ}$ and $20^{\circ}$ cooler than in 2008, yet the stage trends were approximately the same. Thus, the comparison of the 2008 and 2016 flood events does not indicate any definitive relationship between water temperature and stage. A limitation of this analysis of these 
two events is that the water temperatures were in the lower- to midtemperature range and only varied by approximately $20^{\circ}\left(42^{\circ} \mathrm{F}\right.$ to $\left.62^{\circ} \mathrm{F}\right)$. As shown in Figures 3.9 to 3.13, the water temperatures can reach close to $90{ }^{\circ} \mathrm{F}$. Therefore, it is possible that a larger temperature range extending up to the higher temperatures may be required before significant impacts are manifested.

In 2011, the flows increased to approximately 2,300,000 cfs and then began to fall along a curve that was approximately 2 to $3 \mathrm{ft}$ higher than in 2008 and 2016 for a flow of approximately 1,800,000 cfs. Examination of the recessional flows showed that the average water temperature in 2011 was approximately $27^{\circ}$ higher than 2016 but only approximately $7^{\circ}$ higher than 2008. Therefore, the higher stages in 2011 cannot be explained solely by water temperature differences. A more likely explanation is that the longer duration and extreme magnitude of the 2011 flood event may have resulted in a much larger hysteresis loop than in 2008 and 2016.

At Hickman the stages in 2016 were approximately 4 to $5 \mathrm{ft}$ lower than the 2011 stages for a flow of approximately 1,700,000 cfs. Unfortunately, there were no water temperature data available for Hickman. However, based on data at Vicksburg, it follows that the January 2016 water temperature was significantly less, probably in the $30^{\circ}$ range, than the spring flood of 2011.

The literature is replete with studies documenting the effects of water temperature on river stages, but as discussed above, there may be multiple factors driving this phenomenon. Unfortunately, there have been no detailed investigations to identify and evaluate the relative contribution of these causative factors. The precise nature by which water temperature affects sediment transport, bed forms, and stages is a complex issue that warrants further investigation to more completely understand the relative contribution of the various causative factors. 


\section{Summary}

The fact that stage-discharge relations on the Mississippi River are subject to change based on temperature has been well documented at least since the 1960s. Winter (cold water) floods generally produce lower stages than spring/summer (warm water) floods of the same flow magnitude. Researchers have typically attributed this phenomenon to changes in the water viscosity, which in turn, affects the sediment transport, bed forms, and resistance to flow. The underlying processes responsible for these observed trends, however, have not been fully investigated: other processes such as floodplain vegetation changes, antecedent flood conditions or other factors may also be significant contributors.

Stage, discharge, and water temperature data were analyzed at eight stations along the Mississippi River to determine if the observed, lower stages during the 2016 winter flood reflected some shift in the morphologic character of the river that might affect future management of the system. Analysis of long-term specific gage records and stagedischarge comparisons in 2008, 2011, and 2016 did not reveal any significant changes that were contrary to the observed long-term stage trends, typical warm water versus cold water trends, or normal intraannual stage variability. 


\section{Appendix: Points of Contact}

David. P. May

Author, ERDC-CHL

David.P.May@usace.army.mil

Ty V. Wamsley

MRG\&P Technical Director, USACE MVD

Ty.V.Wamsley@usace.army.mil 


\section{References}

Biedenharn, David. S., Mead A. Allison, Charles D. Little, Jr., Colin R. Thorne, and Chester C. Watson. 2017. Large-Scale Geomorphic Change in the Mississippi River from St. Louis, MO, to Donaldsonville, LA, as Revealed by Specific Gage Records. MVD MRG\&P Report No. 10. Vicksburg, MS: U.S. Army Engineer Research and Development Center.

Burke, P. P. 1966. Effect of Water Temperature on Discharge and Bed Configuration; Mississippi River at Red River Landing, Louisiana. Technical Report No. 3. Committee on Channel Stabilization. Vicksburg, MS: U.S. Army Corps of Engineers, Waterways Experiment Station.

Colby, B. R., and C. H. Scott. 1965. Effects of Water Temperature on the Discharge of Bed Material. Geological Survey Professional Paper 462-G. Department of the Interior, U.S. Geological Survey. Washington, DC: United States Government Printing Office.

Fenwick, G. B. 1969. Water Temperature Effects on Stage-Discharge Relations in Large Alluvial Rivers. Technical Report No. 6. Committee on Channel Stabilization. Vicksburg, MS: U.S. Army Corps of Engineers, Waterways Experiment Station.

Franco, J. J. 1968. "Effects of Water Temperature on Bed-Load Movement.” Journal of Waterways and Harbors Division, American Society of Civil Engineers 94(WW3): 343-352.

Hubbell, D. W., and D. Q. Matejka. 1956. Investigations of Sediment Transportation, Middle Loup River at Dunning, Nebraska. U.S. Geological Survey Water-Supply Paper 1476. Reston, VA: U.S. Geological Survey.

U.S. Army Corps of Engineers (USACE), Omaha District. 1969. Missouri River Channel Regime Studies. Sediment Series No. 13B. U.S. Army Corps of Engineers, Omaha District; Missouri River Division.

Vanoni, V. A., and N. Brooks, II. 1957. Laboratory Studies of the Roughness and Suspended Load of Alluvial Streams. Report No. E-68. Pasadena, CA: Sedimentation Laboratory, California Institute of Technology. 


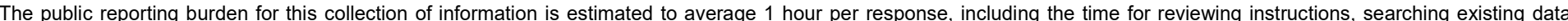

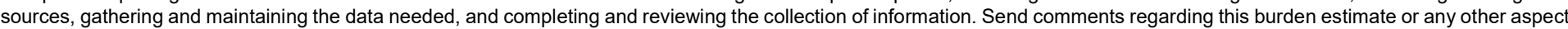

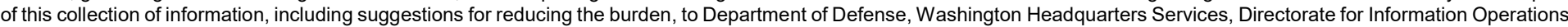

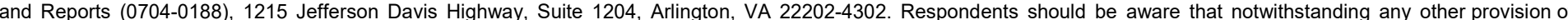
law, no person shall be subject to any penalty for failing to comply with a collection of information if it does not display a currently valid OMB control number.

PLEASE DO NOT RETURN YOUR FORM TO THE ABOVE ADDRESS.

\begin{tabular}{l|l}
\hline $\begin{array}{l}\text { 1. REPORT DATE } \\
\text { November } 2017\end{array}$ & 2. REPORT TYPE \\
& Final Report \\
\hline
\end{tabular}

\section{TITLE AND SUBTITLE}

Mississippi River 2016 Winter Stage Trends

\section{DATES COVERED (From - To)}

5a. CONTRACT NUMBER

5b. GRANT NUMBER

5c. PROGRAM ELEMENT NUMBER

\section{AUTHOR(S)}

David P. May, David S. Biedenharn, Brian S. Johnson, and Edmund Howe

5d. PROJECT NUMBER

127672

5e. TASK NUMBER

5f. WORK UNIT NUMBER

8. PERFORMING ORGANIZATION REPORT NUMBER

7. PERFORMING ORGANIZATION NAME(S) AND ADDRES
U.S. Army Engineer Research and Development Center

Coastal and Hydraulics Laboratory

3909 Halls Ferry Road

MRG\&P Report No. 15

Vicksburg, MS 39180

9. SPONSORING/MONITORING AGENCY NAME(S) AND ADDRESS(ES)

U.S. Army Corps of Engineers, Mississippi Valley Division

Mississippi River Geomorphology and Potamology Program

1400 Walnut Street

Vicksburg, MS 39180 NUMBER(S)

10. SPONSOR/MONITOR'S ACRONYM(S)

MVD

\section{SPONSOR/MONITOR'S REPORT}

NUMBER(S)

\section{DISTRIBUTION/AVAILABILITY STATEMENT}

Approved for public release; distribution is unlimited.

\section{SUPPLEMENTARY NOTES}

\section{ABSTRACT}

During the winter flood of 2016, concerns were raised about the projected stages being higher than observed and whether these differences reflected some significant morphologic change in the Mississippi River that required attention. To address this issue, a review of research related to cold water versus warm water floods was conducted, followed by an analysis of specific gage records and stagedischarge trends, which had been updated to include data from 2014 through 2016. The gage analysis revealed no stage abnormalities tha were considered outside the normal broad-scale trends or typical intra-annual stage variability. Rather, the observed stages appeared to be consistent with typical cold water stage tendencies. Observed stage-temperature data indicate that at the mid-bank and higher flows, there is a significant association between stage and water temperature. The fact that this apparent paradox does exist suggests that the underlying dominant processes for the differences between cold water and warm water flood stages are not yet fully understood: processes such as floodplain vegetation changes, antecedent flood conditions, or other factors may also be significant contributors.

\section{SUBJECT TERMS}

Floods, Mississippi River, River channels, Stream measurements, Water temperature

\begin{tabular}{|l|l|l|}
\hline 16. SECURITY CLASSIFICATION OF: \\
\hline a. REPORT & b. ABSTRACT & c. THIS PAGE \\
Unclassified & Unclassified & Unclassified \\
\hline
\end{tabular}

\begin{tabular}{|}
$\begin{array}{c}\text { 17. LIMITATION OF } \\
\text { ABSTRACT } \\
\text { SAR }\end{array}$ \\
\hline
\end{tabular}

\section{NUMBER OF 19 a. NAME OF RESPONSIBLE PERSON PAGES David May}

31 19b. TELEPHONE NUMBER (Include area code)
$601-634-7543$ 